\title{
Proposing a Framework to Extend the Global Commodity Chain Theory: A Case Based Study with Evidence from Garment Supply Chain
}

\author{
Anand Chand ${ }^{1}$ \\ ${ }^{1}$ School of Management \& Public Administration, the University of the South Pacific, Suva, Fiji Islands. \\ Correspondence: Dr Anand Chand, School of Management \& Public Administration, The University of the \\ South Pacific, Private Mail Bag, Suva, Fiji Islands. Tel: 679- 3232541, E-mail: chand_a@usp.ac.fj
}

Received: September 12, 2017

Accepted: October 18, 2017

Online Published: October 21, 2017

doi:10.5539/mas.v11n11p34

URL: https://doi.org/10.5539/mas.v11n11p34

\begin{abstract}
The traditional Supply Chain Management Theory has been around for few decades. In addition, between 1994 and 2000, another theory by the name of the 'Global Commodity Chain' (GCC) theory was developed by Gary Gereffi from North Carolina University (USA) which is more broader than the Supply Chain Management Theory. The aim of this paper is to revisit and critically examine Gereffi's (1994) GCC theory and attempt to expand its analytical framework from the perspective of a small island country in the Pacific. The research findings highlight some of the limitations which GCC theory and suggest that a full understanding of global commodity chains needs to be reframed and embedded in the context of a country's national social, economic and political environment. The paper argues that GCC theory need to incorporate variables such a as of 'national economic policies', 'role of state' and 'labor' in order to fully account for the complexity of modern supply chains. The paper concludes by arguing that the GCC theory is limited in explaining the true picture in developing small island countries. The paper contributes literature on GCC theory.
\end{abstract}

Keywords: Garment TNCs, GCC Theory; Developing Small Island Countries, International/Global Purchasing, Outsourcing (Make or Buy), Qualitative Data Analysis, Supply Chain Management

\section{Introduction}

Supply chain management is a set of approaches used to efficiently link and coordinate raw materials, production, information flows, logistics and financial flows across the supply chains, so that the right goods of the right amount and quality are produced, supplied and distributed (Dickens, 1992; Meltzer, et al., 2001). In the 1980s, new social science theories emerged in order to explain the role of Transnational Corporations (TNCs) in global shift of production and outsourcing. Some of these theories are Fröbel et al., (1980) 'New International Division of Labor' theory (NIDL), Piore and Sabel's (1984) 'Mass versus Flexible Production' theory', Dicken's (1992) 'Global Shift of Production' theory and Held et al., (1999) 'Globalisation Theory'. These theories were able to explain some of the features of global production but did not specifically use the tool of supply chains and Gereffi's (1994a) 'Global Commodity Chain' (GCC) theory tied to fill this gap.

More than 30 years has lapsed since the emergence of Gereffi's GCC theory and the contemporary global production system is markedly different from that of the 1990s. Furthermore, there exists differences and commonalities in the way GCCs operate in developing small island countries and very few studies have explored GCCs in developing small island countries. Thus the main of this paper is to analyse the GCCs in Fiji. The paper will also identify possible limitations GCC theory and attempts to expand GCC analytical framework so that we can fully capture and understand new trends in global supply chains. The paper uses primary empirical evidence from thirty five garment firms in Fiji to expand GCC theory. Given this scanty literature on garment supply chains in developing small island countries and the lack of rigorous theoretical analysis this paper attempts to fill this research gap by expanding GCC theory. By introducing new variables, this paper asserts that supply chains and global production systems are more complex than previously understood by GCC theory and suggests that there is a scope to extend the existing framework to account for a more complex picture of contemporary supply chains and global economy.

This paper is divided into seven sections. Section one introduces the main objective of undertaking this study. 
Section two provides the theoretical foundations of this study leading to the research gap thereby establishing the scope of this paper. Section three outlines the research methodology as adopted by the authors along with the survey methodology and the data collection procedure. Section four reports the data analysis along with the significant findings of this study. Section five presents the case discussion in context to the Fiji garment industry. Section six attempts to bring out the theoretical and business implications and tries to expand the analytical framework of GCC theory so that we can provide a holistic picture of supply chains. Finally, section seven provides the conclusion, possible limitations of this study and identifies scope for future research.

\section{Literature Review}

\subsection{Literature Review on Supply Chain Management Theory}

There has been substantial published literature available in the domain of global supply chain. Some of the significant ones in context to this papers are by Carter (2004) who has examined the concept of 'Purchasing and Social Responsibility' (PSR) across a large sample of manufacturing and service organizations in the USA. Ellram, et al., (2002) has examined the issue of 'Purchasing and Supply management' (PSM) and found that best practices of PSM led to corporate success. Giunipero, et al., (2008) argued that there is a need for more research that seeks to understand the nature of 'multiple links' in SCM chains and 'networks' rather than just focusing on 'dyadic' and 'inter-firm' relationships. Cai and Yang (2008) have examined the issue of the development of 'cooperative norms' in Chinese buyer and supplier relationships and argued that cooperative norms play a critical role in the governance of the Chinese buyer-supplier relationships. Hilletofth, et al., (2010) have argued that the concept of 'New Product Development' (NPD) not only enables management to coordinate the efficient flow of new products but also has a positive impact on the whole supply chain management. Similarly, Hassler (2003) has argued that any clothing commodity chain has various influential factors, such as the national and global regulatory framework, the societal context of the leading firm and individual clothing firms are embedded. In a study to explore the supply chain of agro food sector, Feivos and Nigel (2015) took a whole chain approach to report significant insight in that sector. Timo Seppala et al., (2014) observed that transfer pricing is a critical issue and that for nation states critical measures like gross domestic product and worker productivity are becoming increasingly imprecise. Kirsten and Sanne (2015) highlighted the role of collaboration in ensuring supply chain resilience.

More specifically, with regards to garment industry, there is a lot of literature on garment supply chains and much of the literature focuses on garment supply chains in developed western and East Asian countries. For example, Bruce, et al., (2004) have examined garment supply chains of the UK and argued that 'lean production' systems have led to reduced 'lead times' in garment supply chains. Adewole (2005) who also examined garment firms in the UK, mentioned that the main problem faced by small firms is an inadequate 'information-sharing structure' and argued that more 'structured information strategies' will provide the efficient flow of accurate and timely information across supply chains and increase their competitiveness. Verma, et al., (2011) have examined the need to improve the logistics of the garment supply chains in order to increase supply chain competitiveness in the global garment market.

Although much has been written on garment supply chains in large developed countries, there is little research and publication on garment supply chains in developing small island countries and no literature on the South Pacific island countries. In the case of Fiji, there is some general literature on the Fiji garment industry. For example, Narayan (1999) focused in general on the issues of export performance, profitability and efficiency in the Fiji garment industry. Chand, et al., (1997) examined the issue of high rates of absenteeism and staff turnover in the Fiji garment industry. Grynberg (1997) has discussed the role of the SPARTECA trade agreement in assisting Fiji to export garments to Australia and New Zealand. Chand (2001) examined the issue of human resource strategies practiced in Fiji garment factories. Chand (2012a) highlighted the Fiji garment supply chains. Furthermore, Chand (2012a) discussed the various wage pay system in Fiji garment industry.

Gereffi (1994a) developed his GCC theory more specifically from Hopkins and Wallerstein's (1986) article titled 'Commodity Chains in the World-Economy Prior to 1800'. Gereffi's best-known contribution on supply chains is the co-edited volume, Supply Chain and Global Capitalism with Miguel Korzeniewicz (1994) where he first developed his theory of the Global Supply Chain (GCC). After this publication, Gereffi wrote extensively and has over the last 20 years further expanded and developed GCC theory through a number of journal articles. Gereffi (1995c) mentioned that the global commodity chains have three main dimensions. Gereffi (1995c) mentioned that the global commodity chains have three main dimensions. Firstly, economic activities of supply chains rotate around a single product. Secondly, there is a geographic dispersion of production, trade, and marketing networks comprised of enterprises of different types and sizes. Thirdly, a global commodity chain has a 
governance structure of control and power relationships between buyers and suppliers.

\section{Limitations of GCC theory: Identified in Literature}

In the mid-1990s, GCC theory had attracted some criticisms by scholars. Firstly, Whitley (1996) argued that GCC theory does not adequately focus on the economic activities that take place within a firm and the strategies used by a firm. Whitley (1996) argued that "The Global Commodity Chain theory de-emphasizes the role of the firm and intra-firm relationships" (Whitley, 1996: 411, my emphasis). Whitley (1996) had instead proposed his own Business Systems theory and argued that his theory was better able to analyse the intra-firm activities. Secondly, Hollingsworth, et al., (1994) and Whitley (1996) argued that GCC theory under-plays the economic activities within and between sectors and the variations within and between sectors in a country. They argued that sector analysis is important and mentioned that variations between sectors exist due to differences in technology, competitive structures, and use of labor and that these issues influence the type of strategies countries use to be internationally competitive. Thirdly, Burch and Goss (1998) and Beynon and Harvey (1999) argued that GCC theory puts too much emphasis on the production node in the supply chain at the expense of non-production nodes such as, 'financiers', 'buyers', 'wholesalers', 'marketers', 'distributors', and 'retailers'. Burch and Goss (1998) in their comparative study of the pineapple and wine industries in Australia argued that the 'wholesalers' and 'retailers' rather than 'producers' were the key controllers of the supply chains. Similar findings were made by Beynon and Harvey (1999) in their comparative study of the tomato industries in the UK and the Netherlands. Fourthly, Froud, et al., (1998) have argued that GCC theory describes a supply chain as a linear theory and does not account for the complex network of economic activities that go on within a supply chain. Froud et. al., (1998) instead proposed a Sector Matrix Theory and argued that it is able to capture the complex linkages in a supply chain. Finally, Selwyn (2012) has argued that although the GCC approach has contributed much to our understanding of processes of globalization and development, it has failed to incorporate the issue of labour and class relations. Selwyn (2012) mentions that evolving capital-labour relations co-determine processes of capitalist expansion and development and these concepts should be brought back to the centre of GCC analysis. In a recent article, Selwyn (2015) argues that 'lead firm chain governance' and 'supplier firm upgrading' attempts constitute strategies and practices that reproduce global poverty and inequality.

\section{Research Methodology}

This paper is based on a qualitative longitudinal study of thirty six garment firms in Fiji over a twenty-year period between 1995-2017. The author have conducted three major studies on the Fiji garment industry. The first research was conducted between 1995-1997 as part of research commissioned by the Fiji Textile Footwear and Clothing Council to examine the reasons behind high absenteeism and staff turnover rates in the Fiji garment industry. The second research was conducted in the period 1999-2001 which involved conducting extensive research in thirty five garment firms. The third research was conducted between 2014-2017. This longitudinal study has provided the authors to have an in-depth understanding of the garment supply chains in Fiji.

The main method of gathering information was interviews. Face-to-face semi-structured interviews were conducted with various stakeholders. Firstly, interviews were conducted with officials of the FTIB, FMTC, FTCFC, and Fiji Ministry of Labour officials to get an overall picture of the Fiji garment industry and more specifically on supply chains. Interviews with officials of the FTIB and FMTC were important because as part of their work they communicate with garment employers, provide advice to them, and keep the official data on each garment factory. Interviews with officials of the FTCFC were also useful because as an umbrella body, it has information on the Fiji garment industry, represents interests of garment employers and lobbies with the government.

Secondly, interviews were conducted with garment factory employers and general managers (key respondents) to find out more about the supply chains they were involved in. Further information and gaps relating to the dynamics of the supply chains were obtained by interviewing line production managers and supervisors. With regards to nature of work, wages, and working conditions interviews were conducted with employees. In addition face-to-face interviews were conducted with officials of the Fiji Ministry of Labour officials to gather insights into the issues affecting labour, especially on imported Chinese female garment from China and Philippines. These interviews enabled us to get a holistic picture of the garment supply chains and capital-labour relationship.

In addition to the above, informal interactions with overseas garment buyers (wholesalers and retailers) who regularly garment factories in Fiji to discuss about give orders, types of garment they want and check the quality of garments. These buyers are from the UK, Europe, Australia, New Zealand and from Pacific Island countries. Some telephonic interviews with garment buyers and retailers in Australia and New Zealand were also conducted to gain additional insight on the dynamics of garment supply chains operations from the overseas buyer's point 
of view.

The answers given by respondents during the interviews were recorded and the content was transcribed and analysed. The authors used three students from the University of the South Pacific to assist in the interview of garment employees. Garment employers and employees were interviewed in three languages namely Hindu, Fijian, and English. The Indo-Fijian respondents were interviewed in Hindi and indigenous Fijians were interviewed in Fijian by indigenous Fijian research assistants and foreign Chinese employers and employees were interviewed in English and Chinese language in case they did not speak good English.

Also, primary and secondary documents relevant to garment industry were reviewed. Relevant documents were collected from the following organisations were reviewed: the Fiji Trade and Investment Board (FTIB), the Fiji Ministry for Trade and Commerce (FMTC), Fiji Bureau of Statistics (BOS) and the Fiji Textile, Clothing and Footwear Council (FTCFC). These primary documents were reviewed to gather information, ownership of firms, when did they start operating in Fiji, and which countries are the exporting to and has there been any changes in exporting trends.

The longitudinal research (rather than a 'one-off' snapshot picture) enabled the authors to investigate the changes taking place in the supply chains over a long period of time and filled the data gaps from earlier fieldwork research trips. By re-visiting the firms, the longitudinal research enabled the authors to explore whether 'industrial upgrading' was taking place in firms.

\section{Research Findings: Fiji Case Study}

The research findings reveal that Fiji garment industry is involved in three garment supply chains and these are as follow:

a) Supply chain type 1 is controlled by the foreign Chinese-owned garment TNC subsidiaries who export garments to the lucrative USA market;

b) Supply chain type 2 is controlled mainly by the Australian and New Zealand-owned garment TNC subsidiaries who export garments to the Australia and New Zealand markets and

c) Supply chain type 3 is controlled by the domestic Indo-Fijian owned-garment firms who mainly export garments to the Australia and New Zealand markets and some to the UK, Europe and the USA markets.

Each of these three supply chain types are discussed in details below. For each chain, the following seven variables were used to analyze the supply chain: ownership of the firm; governance control; market; reasons for producing in Fiji; type of production process involved; level of investment in technology; and whether industrial upgrading is taking place. A comparative analysis of these types are provided in Table 1.

Table 1. Classification of different types of Garment Supply Chains operating in Fiji

\begin{tabular}{llll}
\hline Supply Chain Type & Ownership & Control/Governance & Target Market \\
\hline 1. Overseas Chinese firm & Firms from China, Singapore, & Controlled by Headquarters in China, & USA \\
controlled Garment GCC & Hong Kong, or Taiwan & Singapore, Hong Kong, or Taiwan & \\
2. Australia \& New Zealand & Firms from Australia or New & Controlled by Headquarters in Australia \& & Australia, New \\
firm controlled Garment GCC & Zealand & New Zealand & Zealand \\
3. Fijian firm controlled & Firmed owned by Fiji & Controlled by Fiji nationals & Australia, New \\
Garment GCC & Nationals or joint venture & & Zealand, UK, USA \\
\hline
\end{tabular}

Source: Tabulated by Author (2017)

\section{a) Supply Chain Type 1: Chinese TNC controlled Chains}

The supply chains of type 1 are essentially market driven. The main reason for operating out of Fiji is to take advantage of Fiji's preferential duty-free and quota-free access to overseas markets. Also such types tend to benefit from the financial incentives offered by Fiji under the Tax Free Zones (TFZ) and Tax Free Factories (TFF) plans emulating what the Chinese TNC garment firms are doing in Saipan and Guam (Leung, 1997). Chinese TNCs garment firms are involved in the 'Full Garment Supply' (FGS) and not 'Cut, Make and Trim' (CMT) production schemes because the USA garment buyers (wholesalers and retailers) want FGS and not CMT. The foreign Chinese garment subsidiaries in Fiji do not invest capital in modern technology because they plan to 
leave the country when a better opportunity arises overseas. For example, some foreign Chinese TNC garment firms left Fiji after 2001 and relocated to Africa after the USA passed the 'African Growth and Opportunity Act' (AGOA) trade agreement with African Countries in 2000. There has been hardly any 'industrial upgrading' taking place in Chinese TNCs garment firms in Fiji.

\section{b) Supply Chain Type 2: Australian and New Zealand TNC Controlled Supply Chain}

Such types of supply chain are cost driven-buyer chains in nature. The main reasons for operating out of Fiji are to take advantage of cheap labor in Fiji and to benefit from Fiji's preferential duty-free and quota-free access to the Australian and New Zealand markets via the SPARTECA trade agreement. The Australian and New Zealand garment firms are involved in the 'Cut, Make and Trim' (CMT) production process because the subsidiaries in Fiji are supplying garments to their parent companies in Australia and New Zealand who do the other functions of FGS. Similar to the foreign Chinese firms, most Australian and New Zealand garment firms in Fiji do not invest capital on modern technology because they plan to leave the country in the future when WTO rules will require them to reduce import tariffs. This would result in the Australian and New Zealand garment buyers importing cheaper garments from Asia. Also, there is little 'industrial upgrading' taking place in the Australian and New Zealand garment firms in Fiji.

\section{c) Supply Chain Type 3: Fiji Owned Garment Firms Supply Chains}

Supply chains of this type are both buyer and producer driven. The basic reasons for operating are to take advantage of Fiji's preferential duty-free and quota-free access to the USA market and to make use of financial incentives offered by Fiji under the TFZ and TFF schemes. The Fiji national owned firms are involved in all three types of production systems: CMT, FGS, and OBM. However unlike the foreign Chinese, Australian and New Zealand garment firms, most of the Fiji owned national firms invest capital on modern technology because they are interested in staying in the garment industry for the long term. Also, there is more 'industrial upgrading' taking place in most of the Fiji national owned garment firms.

\section{Limitations of GCC theory: Identified in Fiji's Case Study}

The research findings from Fiji's garment industry reveal that the contemporary global supply chains are more complex than previously analyzed by existing popular GCC theory and suggest that we should extend the analytical framework of GCC theory in order to account for a more complex picture of global supply chains. The research findings from Fiji illuminate six significant variables which the GCC theory is not able to account for and these are discussed next.

\section{i) Silent on the role of Global Institutions in influencing the Chains}

Firstly, the existing GCC theory does not account for how global institutions and forces (such as the World Bank, IMF) influence the establishment of supply chains. In the case of Fiji, the garment industry was established as a result of recommendation by the World Bank Report (1985) that Fiji should change its economic strategy from 'import-substitution' to 'export oriented' and use its cheap labour as a leverage to compete in the global garment industry. The GCC theory does not take into account the influence by global institutions, but instead merely focuses on the 'firm' as a unit of analysis. The GCC theory analysis the level micro issues of the supply chain such as nodes, inter-firm relations, transport, etc. while neglecting the macro global and national government actors which influence supply chains. One of the arguments of this paper is that for us to fully understand supply chains in a holistic context. In reality, we cannot isolate supply chains from the wider global economic environment in which chains are embedded. The GCC theory's analytical framework needs to be extended to capture the holistic picture in which supply chains are embedded.

\section{ii) Silent on the Reasons for Global Shift of Production}

Secondly, the GCC theory stipulates the three main reasons why garment firms from developed countries re-locate to developing countries are: cheap labor, financial incentives and trade agreements. This paper argues that there is a 'basket' of factors which TNCs consider before deciding where and when to relocate. The additional factors which TNCs consider when re-locate to developing countries are physical infrastructure of a country such as developed road, shipping, airfreight facilities, skillful human resources, efficient communication systems, and less lead-time, ease to repatriate profits overseas (banking regulations) and political stability. This paper asserts that there is a multiple set of factors for the global shift of production and not just the availability of cheap labor, financial incentives and markets as put forward by GCC theory.

iii) Absence of National Socio-Economic Policy in Chain analysis

Thirdly, the GCC theory does not account for how national socio-economic policies and institutions can 
influence supply chains (Hassler, 2003). For example, the national policy on direct foreign investment determines the amount of money overseas firms will bring into a developing country how much they borrow locally. Thus, the GCC theory ignores the importance of national socio-economic policies in which supply chains are embedded.

iv) Silent on the role of the State

Fourthly, the GCC theory does not account the role of the state and influence of supply chains. In the social science literature, much has been written on the state institutions and role of state in promoting and facilitating development in a nation (Strange, 1994). One of the main debates in the era of globalisation revolves around the issue of whether the state has lost autonomy and power due to the globalisation process (Strange, 1994). The question that is often asked is whether there has been a 'hollowing out' process of the state by market forces? There are two schools of thought on this issue. On the one hand, there are authors such as Strange (1994) who argue that the powers of 'state' have diminished as a result of increasing power and control by TNC's. On the other hand, there are those (Wade, 1990) who argue that the powers and autonomy of the state have not diminished and the state is still an important player in a national economy and development process (Wade, 1990).

The GCC theory does not take into account for the role of the state' as a crucial player in a national economy and the supply chain. The research findings from Fiji show that the Fijian state has played a major role in the establishment and the growth of the Fiji garment the supply chains. The Fijian state has implemented the policies recommended by the World Bank and IMF to develop the garment supply chains industry and has introduced financial incentives such as Tax Free Zones (TFZ) and Tax Free Factories (TFF) to attract foreign investors to open factories in Fiji. These encouraged foreign Chinese, Australian and New Zealand garment TNCs to relocate to Fiji which led to the exponential growth of the Fiji garment industry. Furthermore, the Fijian state via its financial institution, the Fiji Development Bank (FDB) provided soft loans to overseas investors. Although, the 'state' is mentioned in passing in the GCC theory, the 'state' as a unit of analysis is not fully developed to explain it's role in the establishment, growth ( even decline) of supply chains.

\section{v) Role of Labor Missing}

The fifth limitation is that the unit of analysis of 'the workers', is missing from the GCC theory. The GCC theory gives privileged positions to the 'firm' and the 'node' of supply chain, but fails to examine the contribution of workers in increasing productivity and making a supply chain internationally competitive. The GCC theory in its pre-occupation with the 'firm' and the 'node' of supply chain, the GCC theory leaves labor completely out of the picture. A similar finding was made by Sung (2006) who developed the concept of the 'developmental worker' and argued that in the Singapore case, in addition to the concept of 'developmental state', the skills of workers have led to the success of Singapore's economy following World War Two.

Furthermore, the GCC theory does not take into the role of 'migrant labor' in bringing the wages

down (race to the bottom argument) and the speeding of assembly production lines and subsequent work intensification. For example, the research findings from Fiji show that when Chinese TNCs moves to other countries they also take with them labor from the mainland China. By using cheap Chinese labor in Fiji, foreign Chinese firms have a competitive advantage over the Fiji, Australian and the New Zealand owned firms because they only utilize Fijian labour who are comparatively more expensive vis-à-vis labor. Furthermore, when Chinese 'capital' moves, so does the whole package of 'Chinese punitive labor regime' (Chand, 2012b). The evidence from Fiji shows that Chinese use piece rates, pace-setters and long working hours to exploit workers. The case study of the Fiji garment industry reveals that not only 'capital' is footloose, but so is 'labor'. All Chinese owned garment firms have brought Chinese workers from China which illustrates the point that 'migrant labor' also follows the footstep of 'capital' (Note 1). The GCC theory does capture this issue of the role of 'migrant labor' in supply chains.

\section{Discussion and Expansion of the GCC Theory}

The research findings have significant business implications for supply chains in developing small island countries which are influenced by global financial institutions and forces. For example, research findings from Fiji show that the World Bank (WB) and International Monetary Fund (IMF) influenced the growth of Fiji's garment supply chains. The Fiji garment industry was established by the Fijian government as a result of direct economic policy recommendations by the World Bank and IMF Reports on Fiji (WTO, 1985). As part of the Structural Adjustment Policy (SAP) the World Bank and IMF, Fiji was asked to reduce its wage cost and introduce a competitive garment industry, thus encouraging and facilitating the emergence of garment supply chains (WTO, 
1985). This evidence underscores the point that global forces can initiate, shape and constantly re-shape the internal and external features of supply chains.

The research findings from Fiji show that due to liberal the Fiji government financial lending policies, most TNCS operating in Fiji borrow money from the Fiji Development Bank (FDB) so that when they leave the country they do not incur lot of financial loss. Furthermore, the ethnically-biased lending policies by FDB giving loans to indigenous Fijians has made it easy for foreign Chinese, Australian and New Zealand garment TNCs to use indigenous Fijians as joint-venture partners in order to qualify for loans from FDB. There have been many cases of 'fly-by-night' overseas- owned garment firms who have closed their businesses and left Fiji without informing the government, FDB or the workers and this has affected the supply chains.

The primary empirical evidence from the Fiji garment industry shows that garment buyers (wholesalers and retailers) from rich developed countries are able to make maximum profit by subcontracting the production of garments backwards along the supply chain to the cheapest producer (the scenario of the 'race to the bottom'), who then are involved in 'work intensification' in order to make some profit for themselves. Gereffi's GCC theory needs to be expanded to take into account the 'worker' and 'work intensification' in analyzing supply chains in other regions of the world (Chand 2012b). Hence, any in-depth analysis of a supply chain is hollow without the examination of the 'employee' and this is a key shortcoming of Gereffi's theory.

\section{Conclusion, Limitations and Scope for Future Research}

This study has attempted to critically examine the established and much cited GCC theory and identified the gaps. The researchers provided suggestions on how to expand the existing framework of the Gereffi's theory. The paper argues that GCC theory is not able to comprehensively account for what is going on in garment supply chains in developing small island countries and shows that any discourse on supply chains needs to be reframed and embedded in the context of a broader analysis of national and global socio-economic environments. This paper brings back to center stage the analytical tools of 'global forces', 'national economy', 'state, 'labor', 'migrant labor' and 'reasons for global shift of production' and incorporates them into the GCC theory.

The author has tried to take a holistic view to suggest a more comprehensive framework which can act as a definite refinement of the existing theory. However, the author feels that there is adequate scope for future research in this area so as to generalize this framework to other industry types. The authors also feel that some of the emerging issues like that of maturing of trade agreement and its impact on global supply chain is worth exploring. The GCC theory does not provide an in-depth account of how the variable trade agreement can assist in establishing, facilitating or even killing supply chains. Although the variable trade agreement is mentioned in Gereffi's GCC theory, an in-depth analysis is missing. The research finding from the Fiji garment industry shows that the provision of preferential duty-free and quota-free access to overseas markets such as the USA, UK, Europe, Australia and New Zealand was the key variable (competitive advantage) in establishing the garment supply chains of Fiji. However, this variable could not explored in much depth in this paper.

Another aspect which merits some in-depth research is the importance of the ownership type of a firm. The variable of ownership of a firm is important because it has an impact on other variables in supply chains. One, ownership of a firm determines which country the firm will export garments to. For example, the research findings from Fiji's garment supply chains show that the foreign Chinese owned firms only export to the USA market, the Australian owned firms only export to the Australia market, the New Zealand owned firms only export to the New Zealand markets, and Fiji owned firms export to the Australian, New Zealand and EU markets.

In conclusion, at best, GCC theory is under-theorized in the context of small island developing countries and this paper recommends that more such studies should be done on supply chains in developing small island countries across the globe to get a better understanding of what is going in these countries and so that we can develop and refine the GCC theory further.

\section{References}

Adewole, A. (2005). Developing a strategic framework for efficient and effective optimization of information in the supply chains of the UK clothing manufactures industry. Supply Chain Management: An International Journal, 10(5), 357-366.

Bair, J., \& Gereffi. G. (2000). Local clusters in global chains: the causes and consequences of export dynamism in Torreon's blue jeans industry. World Development, 29(11), 1885-1903.

Beynon, H., \& Harvey. D. (1999). Process of Variation: How Capitalism has Appropriated the Tomato. unpublished report, University of Manchester. 
Bruce, M., Daly. L., \& Towers. N. (2004). Lean or agile: A solution for supply chain management in the textiles and clothing industry? International Journal of Operations and Production Management, 24(2), 151-170.

Burch, D., \& Goss. J. (1998). Global Sourcing and Retail Chains: Shifting Relationship of Power in Australian Agri-foods. unpublished conference paper, Science Policy Research Centre, Griffith University, Queensland, Australia.

Cai, S., \& Yang. Z. (2008). Development of Cooperative Norms in the Buyer-Supplier Relationship: The Chinese Experience. Journal of Supply Chain Management, (44), 55-70.

Carter, C. R. (2004). Purchasing and Social Responsibility: A Replication and Extension. Journal of Supply Chain Management, (40), 4-16.

Carter, C. R. (2011). A Call for Theory: 'The Maturation of the Supply Chain Management Discipline'. Journal of Supply Chain Management, (47), 3-7.

Chand, A. (2001). Human Resource Strategies in Small States: The Case of Garment Factories in Fiji. International Journal of Educational Development, (21), 274-284.

Chand, A. (2012a). Global Supply Chains in the South Pacific Region: A Study of Fiji's Garment Industry, Nova Science Publishers Nova, Inc., New York. USA.

Chand, A. (2012b). At the bottom of global supply chain: - how different really are hourly wage rates and piece rates?' Industrial Relations Journal, 43(2), 171-19.

Chand, A., Szmedra. P., \& Grynberg. R. (1997). Absenteeism and Turnover in the Fiji Garment Industry', Unpublished Report to the United Nations Development Program, Suva, Fiji.

Dicken, P. (1992). Global Shift: The Internationalization of Economic Activity, Paul Chapman Publishing Ltd, London.

Ellram, L. M. et al. (2002). The Impact of Purchasing and Supply Management Activities on Corporate Success'. Journal of Supply Chain Management, (38), 4-17.

Feivos A., \& Nigel P. (NA)Emergent supply chains in the agri-food sector: Insights from a whole chain approach'. Supply Chain Management-An International Journal, 20(4). In Press.

Fiji Bureau of Statistics (BOS) Records: 1995-2014. Suva, Fiji.

Fiji Ministry for Trade and Commerce (FMTC) Records: 1995-2014. Suva, Fiji.

Fiji Textile, Clothing and Footwear Council (FTCFC) Records: 1995-2014. Suva, Fiji.

Fiji Trade and Investment Bureau (FTIB) Records: 1995-2014. Suva, Fiji.

Fröbel, F., Heinrichs. J., \& Kreye. O. (1980). The New International Division of Labor, Cambridge University Press, Cambridge.

Froud, J. et al. (1998). Breaking the Chains? A Sector Matrix for Motoring. Competition and Change, (3), 293-334.

Gereffi, G. (1994a). The Organisation of Buyer-Driven Global Supply Chains: How U.S. Retailers Shape Overseas Production Networks.' In Gereffi, G. and Korzeniewicz. M. (Eds). (1994). Supply Chains and Global Capitalism, Westport: Preager.

Gereffi, G. (1994b). Capitalism, Development and Global Supply Chains. In L. Sklair (ed.), (1994), Capitalism and Development, Routledge, New York.

Gereffi, G. (1995). Global Production Systems and Third World Development.' In B. Stallings (Ed.), Global Change and Regional Response, Boston: Cambridge University Press, 101-142.

Gereffi, G. (1999). International Trade and Industrial Upgrading in the Apparel Supply Chain. Journal of International Economics, 48(1), 37-70.

Gereffi, G., \& Korzeniewicz. M. (Eds). (1994a). Supply Chains and Global Capitalism, Westport: Preager.

Gereffi, G., \& Lee. J. (2012). Why the World Suddenly Cares about Global Supply Chains'. Journal of Supply Chain Management, 48(3), 24-32.

Giunipero, L. C. et al. (2008). A Decade of SCM Literature: Past, Present and Future Implications. Journal of Supply Chain Management, (44), 66-86.

Grynberg, R. (1997). Preferential rules of origin as constraints to Industrialisation: The case of LOME and SPARTECA', paper presented to VIII Pacific Science Inter-Congress, University of the South Pacific, Suva, Fiji. 
Hassler, M. (2003). The global clothing production system: commodity chains and business networks. Global Networks, 3, 513-531. https://doi.org/10.1111/1471-0374.00075

Held, D. et al. (1999). Global Transformations, Polity, Cambridge, 1999.

Hilletofth, P., Ericsson. D., \& Lumsden. K. (2010). Coordinating new product development and supply chain management'. International Journal of Value Chain Management, 4(1/2), 170-192.

Hollingsworth, J. R. Schmitter. P. C., \& Streeck. W. (Eds.) (1994). The Case Studies of Sectoral Analysis, Blackwell Publishers, London.

Interviews with Garment Employers, Managers, Workers, and Officials of the Ministry of Labour: Various years: 1995-2012. Suva. Fiji.

Kirsten S., \& Sanne Schilder. (2015). The role of collaboration in supply chain resilience. Supply Chain Management-An International Journal, 20(4), In press.

Leung, H. C. (1997). Local lives and global supply chains: Timing, networking, and the Hong Kong-based garment industry, 1957-1993. unpublished doctoral dissertation, The University of North Carolina, USA.

Mentzer, J. et al. (2001). Defining supply chain management', Journal of Business Logistics, 22(2), 1-25.

Narayan, P. K. (1999). Fiji's Export-led Garment Industry: An Analysis of Export Performance, Profitability and Efficiency', Working Paper (99:2), Centre for Development Studies, University of the South Pacific, Suva, Fiji.

Piore, M. J., \& Sabel. C. F. (1984). The Second Industrial Divide: Possibilities for Prosperity, Basic Books, New York.

Ramirez, P., \& Rainbird. H. (2010). Making the connections: bringing skill formation into global value chain analyses, Work Employment Society, (24), 699-705.

Sabastian P., \& Jan O. (2015). Product architecture and supply chain design: A systemic review and research agenda. Supply Chain Management-An International Journal, 20(1), 98-112.

Selwyn, B. (2012). Beyond firm-centrism: re-integrating labour and capitalism into global commodity chain analysis, Journal of Journal of Economic Geography, 12(2012), 205-226.

Selwyn, B. (2015). Commodity chains, creative destruction and global inequality: A class analysis. Journal of Economic Geography, 15, 253-274.

Sung, J. (2006). Explaining the Economic Success of Singapore: The Developmental Worker as the Missing Link, Edward Elgar, Camberley.

The Fiji Times newspaper articles: Various Years: 1998-2014. Suva, Fiji.

Timo S., Martin K., \& Ali, Y. K. (2014). Global Supply Chain and transfer pricing', Supply Chain Management-An International Journal, 19(4), 445-454.

Verma, A., Seth. N., \& Singhal. N. (2011). Enablers of competitiveness: an interpretive structural theoryling theory. International Journal of Value Chain Management, 5(3/4), 212-231.

Wade, R. H. (1990). Governing the Market: Economic Theory and the Role of Government in East Asian Industrialization, Princeton University Press, Princeton, NJ.

Whitley, R. (1996). Business Systems and Global Commodity Chains: Competing or Complementary Forms of Economic Organisation? In Competition and Change, (1), 411-425.

World Bank. (1985). Fiji: Restoring Growth in a Changing Global Environment, Washington. DC.

\section{Note}

Note 1. Foreign Chinese firms have also brought Chinese workers to work in other industries such as restaurants, road buildings and construction.

\section{Copyrights}

Copyright for this article is retained by the author(s), with first publication rights granted to the journal.

This is an open-access article distributed under the terms and conditions of the Creative Commons Attribution license (http://creativecommons.org/licenses/by/4.0/). 